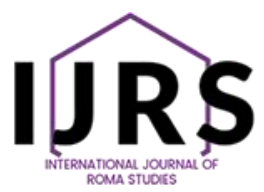

Hipatia Press

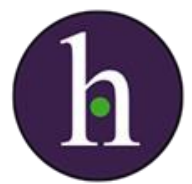

Instructions for authors, subscriptions and further details:

http://ijrs.hipatiapress.com

\title{
Spotlight on voices from the community: The importance of empowerment through the Erasmus+ Nefeli Project for Roma women
}

Theofano Papakonstantinou ${ }^{12}$ and Dimitrios Alexandros Ladopoulos ${ }^{2}$

1) Aristotle University of Thessaloniki, Greece

2) Alternative Innovative Development, Greece

Date of publication: March $15^{\text {th }}, 2021$

Edition period: March 2021 - July 2021

To cite this article: Papakonstantinou, T., \& Ladopoulos, D. (2021).

Spotlight on voices from the community: The importance of empowerment through the Erasmus+ Nefeli Project for Roma women. International Journal of Roma Studies, 3(1), 97-105. doi: 10.17583/ijrs.2020.7909

To link this article: http://dx.doi.org/10.17583/ijrs.2020.7909

PLEASE SCROLL DOWN FOR ARTICLE

The terms and conditions of use are related to the Open Journal System and to Creative Commons Attribution License (CCAL). 


\section{Spotlight on voices from the community: The Importance of Empowerment through the Erasmus+ Nefeli Project for Roma women}

Theofano Papakonstantinou

Aristotle University of

Thessaloniki \& Alternative

Innovative Development, Greece
Dimitrios A. Ladopoulos

Alternative Innovative

Development, Greece

\section{Abstract}

The Erasmus+ Nefeli Project held a weeklong training (September 21-25, 2020) for women from all walks of life and welcomed over 25 participants. Women from the UK, Europe and abroad attended the training and engaged in lifelong learning using the arts and intangible cultural heritage practice, learning about techniques that they can apply in their contexts. Nefeli's training was an exchange of know-how and material of Non-Formal Learning activities between organisations of the consortium and focussed on offering the participants a way to improve their methods and quality of work and gain more results in terms of agency for women from vulnerable communities.

The participants all gained a Europass Mobility certificates as well CPD certificates. Prior to the training, the team held a social media campaign where we asked Roma and migrant women to answer three questions around what lifelong learning means.

Keywords: Lifelong Learning, Roma, Nefeli Project, Women, Grassroots women. 


\section{Enfoque en las voces de la comunidad: La importancia del empoderamiento a través del proyecto Erasmus+ Nefeli para las mujeres gitanas}

Theofano Papakonstantinou

Aristotle University of

Thessaloniki \& Alternative

Innovative Development, Grecia
Dimitrios A. Ladopoulos

Alternative Innovative

Development, Grecia

\section{Resumen}

El Proyecto Erasmus + Nefeli celebró una formación de una semana (21-25 de septiembre de 2020) para mujeres de todos los ámbitos de la vida y recibió a más de 25 participantes. Mujeres del Reino Unido, Europa y el extranjero asistieron a la capacitación y participaron en el aprendizaje permanente utilizando las artes y la práctica del patrimonio cultural inmaterial, aprendiendo sobre técnicas que pueden aplicar en sus contextos. La formación de Nefeli fue un intercambio de know-how y material de actividades de Aprendizaje No Formal entre organizaciones del consorcio y se centró en ofrecer a las participantes una forma de mejorar sus métodos y calidad de trabajo y obtener más resultados en términos de agencia para mujeres de vulnerabilidad. comunidades. Todos los participantes obtuvieron certificados de movilidad Europass y certificados CPD. Antes de la capacitación, el equipo llevó a cabo una campaña en las redes sociales en la que les pedimos a las mujeres romaníes y migrantes que respondieran tres preguntas sobre lo que significa el aprendizaje permanente.

Palabras clave: Aprendizaje No Formal, Gitano, Proyecto Nefeli, Mujeres, Mujeres de base 


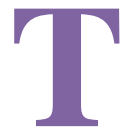

he empowerment of women is an ongoing effort to establish equal opportunities for learning, employment, life and the right to personal choice. Providing equal opportunities for women and introducing support measures for them, requires the formation of individual, social and political capital that will understand the existing gender inequalities and address them. To achieve the above, it is important to have learning opportunities for women, which will enable them to take initiatives to improve their living conditions, raise public awareness and motivate actions aimed at social change.

Women who want to escape from a toxic environment need, in addition to psychological and a number of other support systems in place, they need to acquire skills that will help them in their subsequent personal and professional development. With this backdrop the European program Erasmus+ Nefeli Project - Support \& Empower Women Autonomy was developed and based on the fact that education is able to provide the appropriate opportunities for development and improvement of the life of individuals, transform his/her ideas and provide opportunities, knowledge and skills for the improvement of his/her position within the society.

Coordinator of the European two-year project is the Alternative Innovative Development (AID) organization from Greece and partners with Federació d'Associacions Culturals i Educatives de Persones Adultes (FACEPA) from Spain, Coventry University from the United Kingdom and Amrita from Hungary. All partner organizations are working on gender issues and the empowerment of women, especially for vulnerable groups including Roma, refugees, migrants. The project employs different methodologies and has as a main target group, Roma women. Each partner involved in the project works closely with this community and engages them in a number of ways.

The purpose of the project is the exchange best practices, know-how and methodologies, while also train and provide a series of trainings for people working in organizations whose focus is on the training of women and vulnerable groups. Nefeli project provides its key stakeholders many resources, opportunities and training sessions which transfers evidenced-based methods which equipt individuals to support vulnerable women and girls. 


\section{Activities}

The project started in September 2019 and was scheduled to end in September 2021. However, due to the COVID-19 pandemic it was extended until March 2022, having a duration of 31 months. The main source of funding for the project is the Hellenic State Scholarship Foundation and Erasmus +.

The main activities of the program include:

- Two five-day trainings for grassroot women and adult trainers on the methodologies of the organizations

- Implementation raising awareness actions for the general public

- Three transnational meetings for the coordination of the project

- The creation of a handbook for trainers in terms of using the methodologies of partner organisations.

Until March 2021, there have been two transnational meetings, three public awareness campaigns and a five-day training on the AID methodology based on the Mezirow Transformational Learning and the use of art to develop critical thinking, and Amrita's methodology based on the Waldorf Education \& Integrated Pedagogical Approach adapted for adults.

Of interest to this article is the project's latest 5-day training held in September 2020, online. Initially, it was envisaged that the training would be carried out in Greece, however due to COVID-19 it was conducted through distance learning. It was expected that a minimum of twelve people planned to attend the training, but the team recruited nineteen women total. Given the advantage of e-learning to enable the participation of additional people at no cost and after examining the motivation and profile of the participants, it was decided to involve additional people in online education. Specifically, instead of 12 people, 8 additional women participated, coming from disadvantaged backgrounds, while five out of eight came from other countries (Germany, Slovakia, Serbia, Poland), a total of nineteen women participated, of which Fifteen were Roma. 
The topic of empowerment, the dynamic of the program as well as the possibility of attending the training through distance education, gave a strong incentive to the grassroot women, and the project welcomed women from several European countries. There was a strong interest from low-skilled women, and organizations that support vulnerable communities to participate in the training.

A questionnaire was created to evaluate the training and based on the qualitative research, the participants were asked to express their views. In the analysis of the questionnaire, the views of the Roma women were analyzed exclusively and a snapshot of their experiences are included below. This article is not pretending to critically analyse the project or the specific training mentioned, but rather is attempting to offer an overview of the September 2020 training and the voices of the Roma women that participated. To do this, the questionnaire will be used as a reference to reflect on the event.

The questionnaire was divided into three parts:

- Part 1 - Reflecting the views on Empowerment

- Part 2 - Reflection of views on education

- Part 3 - Demographic data

\section{Part 1 - Reflecting the views on Empowerment}

The five questions in the first part concerned the opinions of Roma women on issues of equality, financial independence, state and family support measures for their empowerment.

On issues of equal treatment, Roma women claimed that they realize that progress has been made, but they also highlighted that they continued to live in a male-dominated society and that women's cultural identity and position played a key role in equal treatment, so education was important. family and parents.

As a positive conclusion, I see tremendous progress for Roma women in advancing towards equal treatment compared to 10 or 20 years ago. (Participant from Training)

Although we have made progress, we have not yet reached equal treatment because we live in a society where male chauvinism still 
prevails, and we must deal with it through "education". There are many cultures in which the role of women has been the same for centuries, the home and the family ... Tradition is cultivated by parents in children, so there is no progress for them. (Participant from Training)

In the question regarding how important they consider their economic and social independence, the participants answered that it plays a very important role as financial independence makes equality possible.

I think it is more important to be professionally independent, because if you are treated equally, you are socially and financially independent. (Participant from Training)

I do not think it should be like that, but in reality, the economy we live in is often the obstacle. (Participant from Training)

As for the question of how they will achieve independence and autonomy, they all gave the same answer through education.

The key for all women around the world is to have access to education. (Participant from Training)

When asked what kind of measures the state and the family can take in order to achieve equality and what else all citizens should know about the empowerment of women, the participants answered that both the government and the family must stand, practically next to the struggle of women. Equality should be a priority in the political decisions of governments. They also noted that supporting and educating women is something we must not forget.

First of all, families need to give little girls the opportunity to go to school. After that, a more informed society should not exclude women and should take action by creating organizations that will empower them. (Participant from Training)

Governments need to fund these organizations and give women access to all aspects of life. (Participant from Training) 


\section{Part 2 - Capturing views on education}

In the second part of the questionnaire, participants were asked about the structure of the program, what impressions they left and if it helped them, if they have participated in something similar in the past, what they found useful and what they did not suggest and what they would suggest for future training.

In the majority, the program received positive feedback from the participants. The largest percentage had participated in similar programs in the past through its cooperation with partner organizations and only a small percentage had never attended. All women showed a great interest in continuing to attend similar programs, as they strengthen selfconfidence, gain knowledge, help them realize issues related to their lives, how to deal with their families and develop friendships with women who face the same challenges.

I found the piece on how to help women to be confident particularly useful. We must not say that they cannot do it because no one in the community has done it before. We can be the first to start the change in empowerment. How to do this? How to convince their families? Where to start? How can they do this without having to change tradition or offend others? (Participant from training)

\section{Part 3 - Demographics}

The third and last part of the questionnaire was about the educational background, their marital status, their employment and if they have satisfactory financial earnings and how they could improve it as well as additional information about themselves.

The educational background of the participants varies with the majority having attended secondary education and a small percentage having attended higher education. Most of the women were married with children, while there was a very small percentage of women divorced with children and unmarried. Most of them didn't work and those who worked, their earnings were mostly satisfactory, but it could be improved. 
In the last question where women had the opportunity to comment with their own comments, they stated the following:

I come from a traditional Roma community (Gabor community) that usually stops accessing education as soon as you reach the age of 1214. Reducing the phenomenon can only be done by using different ways of formal and non-formal education for Roma women. "Access to Roma education in the future will empower other Roma women from isolated and traditional communities to apply. (Participant from training)

The fact that I went to university, I have my job, I am an autonomous person, does not mean that I should remain inactive in the emancipation of women. (Participant from training)

I consider myself lucky because my parents have supported me since I was a child in my education. I think this is what we all need to do now ... support your children to the fullest to study what they want, in what they are passionate about. (Participant from training)

Programs and trainings like these motivate me to become better and realize what steps I need to take in my life. For a long time I was limited to the social needs of the Roma community that I grew up with and through these programs I saw what I really want in my life. (Participant from training)

I was helped by Drom Kotar and graduated from school at 31 (it is never too late). At this age I am preparing for my exams at the University. My purpose with this comment is to inform you that through clubs, in this case Drom Kotar Mestipen, we can educate ourselves and that we Roma women want to educate ourselves to succeed, just like any other another, position improvements. (Participant from training)

I have completed a law degree and am currently studying individual modules related to social mediation (the modules correspond to the content level of the degree, but I do them through non-formal education). (Participant from training) 
The large number of Roma women participated in the training as well as their answers as a whole, highlight their need to participate in empowerment programs that aim to provide them with knowledge, qualifications and skills. Roma women, although coming and living in different countries from all over Europe, seem to recognize the progress that has been made on the position of women in many areas, but stress that there is room for improvement in gender equality. They consider their financial independence to be a factor in strengthening and improving their position and they believe that it is achieved through the access of girls and women to education. The participation of women in empowerment programs is very important, that's why they claim that should be implemented by organizations and funded as a measure of support by states. Through these programs, women share experiences with other women and common concerns, participate in discussions about how they can cope with the challenges they experience (husband, family, community) and create a collective sense of security and confidence that other women can and do exist who have the same dilemmas. They take the courage to differentiate their choices from those of the majority of the community in which they live.

\section{Conclusion}

The results show the important multidimensional impact that the pandemic has had on Women's empowerment is a multidimensional issue, which must be approached from many perspectives and in different ways, depending on the profile of women, their needs and the particularities of their family and cultural environment.

As Bourdieu (1986) states, the formation of an individual's social, political self depends on all the opportunities provided to him in his life. The cultural capital which is connected with cultural and other knowledge, the way of the individual's behavior, the educational supplies, the environment that grows up and his qualifications, create a specific context by limiting or expanding the opportunities in his life. The social disadvantages of the non-socially favored in this case are exacerbated. Universal education facilitates the alleviation of 
inequalities and enables individuals to develop skills and abilities that will enable them to have better access to goods and services, and therefore a quality of life.

In the case of women, in order to be able to claim their rights, to become autonomous, to become independent and to move away from toxic environments, the training suggested that it is necessary to develop the appropriate mental, cognitive, aesthetic and other skills that will help them recognize the discrimination they suffer, to envision their future and to plan their steps. Educating and raising awareness of their rights, inequalities, identity issues, as well as workshops on skills development, confidence and self-awareness, and, of course, reflection on adopted views and attitudes are key tools for transforming and empowering women.

As a final note, many of the women involved in the training supported the Nefeli project's online social media campaign for the United Nation's 16 days of activism campaign. The project helped produce a film called Grow and Glow where women who self-identified as migrants, Roma, marginalised, academics and artists participated. The co-created film kickstarted the UN's 16 days of activism campaign and linked with the November 25th End Violence Against Women Day. The women came up with the "Grow and Glow" slogan to show their solidarity with women and those victims of domestic abuse.

\section{Acknowledgements}

We would like to thank the associations that supported the Project Nefeli Training in September and to all of the women who attended and generously engaged with the materials.

\section{References}

Bourdieu, P. (1986). «The forms of capital», In: Richardson, J.G. (Ed.), Handbook of Theory and Research for the Sociology of Education, New York: Greenwood Press, pp. 241-258 
Theofano Papakonstantinou is an adult trainer, $\mathrm{PhD}$ candidate of Aristotle University of Thessaloniki and Project Manager of Empowerment programs for women in Alternative Innovative Development organisation. Greece

Dimitrios Alexandros Ladopoulos is an adult trainer, Project coordinator of European projects at Alternative Innovative Development organisation. Greece

Contact address: contact.aidorg@gmail.com 